\title{
EKSISTENSI KURIKULUM PESANTREN MU'ADALAH DI ERA GLOBAL
}

\author{
Oleh: \\ Wawan Herry Setyawan 1 \\ Universitas Islam Kadiri \\ wawansetyawan225@gmail.com
}

\begin{abstract}
how the curriculum implementation challenges and opportunities after published government regulations about education schools and diniyah through PMA numbers 13 and 18 in 2014th. Curriculum of Boarding school Salaf obtained Mu'adalah or equalization which is using yellow book and the general education curriculum while the curriculum in a modern boarding school known as the Islamic Dirosah Mualimin pattern. It means learning curriculum that applies classical books with the strengthening of the Arabic language in which the learners (students) can independently examine any kind of book in the future. Challenge of Mu'adalah does not require students following national exams.
\end{abstract}

Key words: Curriculum, Education Boarding school, Mu'adalah.

\section{A. Pendahuluan}

Kata pesantren sendiri berasal dari akar kata santri dengan awalan "Pe" dan akhiran "an" berarti tempat tinggal para santri. Zamakhsari berpendapat bahwa istilah santri berasal dari bahasa Tamil, yang berarti Guru mengaji. ${ }^{2}$ Setelah Islam masuk dan tersebar di indonesia, sistem tersebut kemudian diambil oleh Islam. Istilah pesantren sendiri seperti halnya istilah mengaji, langgar, atau surau di Minangkabau, Rangkang di Aceh bukan berasal dari istilah Arab, melainkan India. ${ }^{3}$ Sebagai sistem pendidikan tertua di Indonesia, pesantren bukan hanya eksis sebagai sistem namun pesantren juga mampu menampilkan dirinya sebagai pilar utama pendidikan di Indonesia dengan kekhasan masing-masing dan kontribusinya kepada pembangunan manusia Indonesia seutuhnya.

\footnotetext{
${ }^{1}$ Penulis adalah Dosen Tetap Prodi Pendidikan Bahasa Inggris Fakultas Keguruan dan Ilmu Pendidikan Universitas Islam Kadiri.

2 Dhofier, Zamakhsyari. Tradisi Pesantren, (Jakarta: LP3ES. 1983).

${ }^{3}$ Steenbrink. A. Karel. Pesantren Madrasah Sekolah (Pendidikan Islam Dalam Kurun Waktu Moderen). (Jakarta: Dharma Aksara, 1986). 
Potret Pesantren pada dasarnya adalah sebuah asrama pendidikan Islam tradisional dimana para siswanya tinggal bersama dan belajar ilmuilmu keagamaan di bawah bimbingan guru yang lebih dikenal dengan sebutan kiai. Asrama untuk para siswa tersebut berada dalam komplek pesantren dimana kiai bertempat tinggal. Disamping itu juga ada fasilitas ibadah berupa masjid. Biasanya komplek pesantren dikelilingi dengan tembok untuk dapat mengawasi arus keluar masuknya santri. Dari aspek kepemimpinan pesantren kiai memegang kekuasaan yang hampir-hampir mutlak.

Pesantren sebagai salah satu "warisan" lembaga pendidikan Islam tertua di Indonesia (indigenous) memiliki peran yang sangat penting dalam pembangunan bangsa. ${ }^{4}$ Sudah sejak awal berdirinya, pesantren selalu terlibat dalam persoalan-persoalan kebangsaan. Melalui kepemimpinan para ulama atau kiai yang memiliki kekuatan spiritual, iman yang teguh, keikhlasan berjuang, dan ketangguhan moral, pesantrenpesantren yang tersebar di pedesaan-pedesaan telah berperan besar dalam menjaga keutuhan bangsa Indonesia dari upaya pemecah-belahan penjajah. Peran dan posisi seperti itu akan terus berjalan dan dilakukan oleh para ulama sebagai perwujudan kecintaan pada tanah air, kesadaran akan perlunya kedamaian dan perdamaian, kesetaraan nilai-nilai kemanusiaan, dan komitmen pada keutuhan negara Indonesia sebagai bangsa yang besar, luas, dan bermartabat.

Pendidikan keagamaan Islam yang dipresentasikan oleh pesantren adalah pendidikan yang mempersiapkan peserta didik untuk dapat menjalankan peranan yang menuntut penguasaan pengetahuan tentang ajaran agama Islam atau menjadi ahli ilmu agama Islam dan mengamalkan ajaran againa Islam.

Penerapan totalitas pendidikan dengan mengandalkan keteladanan, penciptaan lingkungan dan pembiasaan melalui berbagai tugas dan kegiatan sehingga seluruh apa yang dilihat, didengar, dirasakan dan dikerjakan oleh santri adalah pendidikan. Selain menjadikan keteladanan sebagai metode pendidikan utama, penciptaan miliu juga menjadi kunci keberhasilan sebab lingkungan pendidikan itulah yang sesungguhnya mendidik.

Tingginya minat orangtua mempercayakan pendidikan anak kepada lembaga pendidikan pesantren menjadi perhatian Kementerian

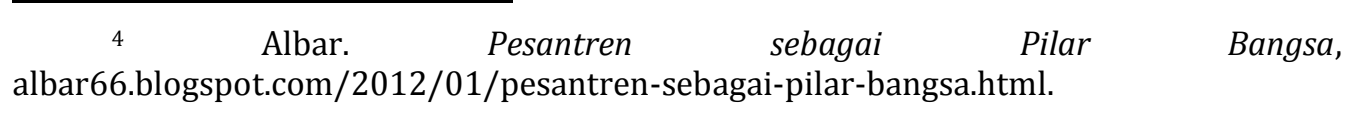

$408 \mid$ JURNAL LISAN AL-HAL 
Agama (Kemenag). Kemenag menilai, banyak kelebihan yang didapat siswa ketika belajar di pesantren. Terlebih lagi, pesantren juga merupakan pendidikan khas Indonesia. "Kelebihan dari pendidikan di pesantren adalah selain selain dididik ilmu pengetahuan, pesantren juga melangsungkan pendidikan karakter," kata Menteri Agama (Menag) Lukman Hakim Saifuddin.

Data tahun 2012 yang dihimpun oleh Ditjen pendis kemenag RI menunjukkan bahwa jumlah pesantren mencapai 27.230 lembaga dengan jumlah santri mencapai 3.759.450. Data ini menunjukan setidaknya ada 3.004.807 anak yang tercatat sebagai santri mukim (menginap) $(79,93 \%)$. Sisanya, sebanyak 754.391 untuk santri non mukim5. Dengan diterbitkanya Peraturan Menteri Agama nomor 13 dan 18 tahun 2014,6 tentang pendidikan pesantren dan diniyah membuka peluang pesantren untuk menjadi destinasi utama pendidikan di tanah air dengan segala tantangan dan problematikanya. Sejauh ini mampukah pesantren menjawab tantangan ini.

Dari konteks di atas masalah yang dibahas dalam tulisan ini yaitu tentang bagaimanakah kurikulum Mu'adalah di pondok pesantren pasca diterbitkanya peraturan pemerintah tentang pendidikan pesantren dan diniyah melalui Peraturan Menteri Agama nomor 13 dan 18 tahun 2014? Dan Apakah tantangan dan peluang penerapan kurikulum Mu'adalah pasca diterbitkanya peraturan pemerintah tentang pendidikan pesantren dan diniyah melalui Peraturan Menteri Agama nomor 13 dan 18 tahun 2014? Hasil dari penelitian ini bertujuan untuk mengetahui kurukulum Mu'adalah di pondok pesantren pasca diterbitkanya peraturan pemerintah tentang pendidikan pesantren dan diniyah melalui Peraturan Menteri Agama nomor 13 dan 18 tahun 2014. Selain itu hasil penelitian ini bertujuan untuk mengetahui tantangan dan peluang penerapan kurikulum Mu'adalah pasca diterbitkanya peraturan pemerintah tentang pendidikan pesantren dan diniyah melalui Peraturan Menteri Agama nomor 13 dan 18 tahun 2014.

\section{B. PEMBAHASAN}

1. Kurikulum Mu'adalah

Hadirnya era globalisasi dan timbulnya modernisasi di berbagai

${ }^{5}$ Ditjen Pendis Kemenag RI | Analisis Data Pendidikan Islam. pendis.kemenag.go.id/index.php?a=artikel\&id2=analisis2011.

6Peraturan menteri Agama republik Indonesia Nomor 13 tahun 2014 Tentang Pendidikan keagamaan islam. Lihat PMA No 18 tahun 2014 (PMA No 18 Tahun 2014) Tentang Satuan Pendidikan Mu'adalah Pada Pondok Pesantren. 
bidang, pendidikan pesantren terkena imbasnya. Sebagian pesantren bukan hanya mengajarkan ilmu-ilmu agama, tetapi juga ilmu-ilmu umum. Karena itu untuk memudahkan pembinaannya, Kementerian Agama membagi madrasah menjadi dua jenis. Pertama, adalah madrasah yang disamping mata pelajaran agama sebagai pelajaran pokok, memasukkan pula mata pelajaran umum dalam kurikulumnya. Kedua, adalah madrasah yang semua mata pelajarannya agama, atau dikenal dengan Madrasah Diniyah. ${ }^{7}$ Sebagian Madrasah Diniyah system pembelajarannya tetap mengikuti pola-pola lama yang lebih dikenal dengan Madrasah Salafiyah. ${ }^{8}$ Sedangkan madrasah diniyah yang sistem pembelajarannya mengalami beberapa pembaharuan tetap disebut Madrasah Diniyah.

Adanya perubahan tersebut terdapat dua kelompok pandangan terhadap eksistensi madrasah diniyah. Kelompok pertama memandang bahwa madrasah perlu dipertahankan sebagai lembaga tafaqquh fi al din. ${ }^{9}$ Kelompok kedua berpandangan bahwa madrasah disamping sebagai lembaga tafaqquh fi al din, lulusan madrasah diniyah perlu mendapat pengakuan kesetaraan (mu'adalah).

Keberadaan Pondok Pesantren dengan melihat perannya selama ini tidak lain bertujuan memperjuangkan tegaknya nilai-nilai religius serta berjihad dalam rangka mentransformasikan segala ilmu yang dipelajari ke dalam proses pertumbuhan dan perkembangan masyarakat. Tujuan yang dimaksud adalah agar kehidupan masyarakat berada dalam kondisi berimbang (balanced) antara aspek duniawi dan ukhrawi. Ada dua macam

7 Marwan Saridjo, Bungan Rampai Pendidikan Agama Islam, (Jakarta: Dirjen Bimbaga Islam, 1997/1998), hlm. 145-146.

8 Kata salafiyah menurut kamus Al Munjid dari kata dasar (masdar) سلف ,سلف يسلف artinya telah berlalu dan selesai, orang-orang dulu/lama. Dalam konteks yang سلفا dikaitkan dengan nama madrasah, yang dimaksud madrasah salafiyah adalah sebuah lembaga pendidikan agama Islam yang kurikulumnya menggunakan kitab-kitab karya ulama terdahulu. Banyak para ulama, kyai, haba'ib menyebut Salafiyyah yang identik dengan Ahlussunnah wal jama`ah, seperti Yayasan Pendidikan Salafiyah. Maksudnya bahwa yayasan itu mengelola pendidikan yang berdasarkan ajaran Islam ahlussunnah wal jama`ah, yaitu ajaran Islam yang mendasarkan ajarannya bersumber kepada : Al Qur`an, Hadist, ijma`dan qiyas. Istilah Salafiyah juga dipakai pemerintah untuk memberi nama pesantren yang tidak memiliki lembaga pendidikan formal, tetapi memenuhi syarat sebagai penyelenggara wajib belajar Pendidikan Dasar 9 tahun, sehingga berhak mendapat bantuan (BOS) dari pemerintah sebagaimana SKB yang dikeluarkan oleh Menteri Agama dan Menteri pendidikan Nasional Nomor: MA/86/2000 dan $\mathrm{I} / \mathrm{U} / \mathrm{KB} / 2000$.

${ }^{9}$ Marwan Saridjo, Bungan Rampai Pendidikan Agama Islam, 161

410 JURNAL LISAN AL-HAL 
model pesantren di Indonesia yaitu salafiyah ( tradisional) dan asyiah (modern).

Pesantren juga memiliki kontribusi dalam Program Wajib Belajar Pendidikan Dasar Sembilan tahun (wajar dikdas) yang dilaksanakan oleh Kementerian Agama ${ }^{10}$. Dengan mempertimbangkan kondisi dan wilayah geografis Indonesia yang sangat luas, dengan latar belakang sosial, budaya, dan ekonomi pendidikan yang heterogen, pesantren mempunyai peran strategis dalam melaksanakan program ini. Program wajib belajar pendidikan dasar sembilan tahun selain melalui satuan pendidikan formal MI dan MTs juga dilakukan melalui Pondok Pesantren Salafiyah dan Pendidikan Kesetaraan (Paket A dan B).

Pondok Pesantren Salafiyah adalah pesantren yang memiliki tradisi lama. Sejak pencanangan gerakan program wajib belajar pendidikan dasar sembilan tahun melalui Inpres Nomor 1 tahun 1994, Pondok Pesantren Salafiyah telah ditetapkan sebagai salah satu pola pendidikan dasar dengan "perlakukan tersendiri" dan penyetaraannya dengan pendidikan dasar. Pendidikan Kesetaraan (Paket A dan B) adalah pendidikan yang disetarakan dengan MTs. Seiring dengan dibukanya program Wajar Dikdas sembilan tahun pada Pondok Pesantren Salafiyah dan Pendidikan Kesetaraan (Paket A dan B), jumlah Pondok Pesantren penyelenggara pendidikan kesetaraan dari tahun ke tahun mengalami peningkatan. Ada pula Pendidikan Kesetaraan paket C pada Pondok Pesantren. Saat ini ada 903 Pondok Pesantren menyelenggarakan Pendidikan Kesetaraan (Paket C) dengan jumlah santri dan warga belajar sebanyak 46.374 orang.

Di samping Pondok Pesantren Salafiyah ada pula Pondok Pesantren Mu'adalah yaitu satuan pendidikan keagamaan yang disetarakan dengan Aliyah/SMU. Setelah lahirnya PP Nomor 55/2007 tentang Pendidikan Agama dan Keagamaan, keberadaan Pondok Pesantren Mu'adalah ini akan diarahkan menjadi Pendidikan Diniyah Menegah Atas (PDMA) yang merupaka pendidikan keagamaan Islam format tingkat menengah. Saat ini, Pondok Pesantren Mu'adalah ini dilaksanakan di 38 Pondok Pesantren di Indonesia dengan jumlah santri peserta program Mu'adalah sebanyak 61.744 dan dibimbing oleh 4635 guru/ustadz. ${ }^{11}$ Berkaitan dengan guruguru pesantren itu sendiri terutama hak dan kewajibannya kalau dia ingin

10 Departemen Agama RI Paparan Direktur Jenderal Pendidikan Islam Dalam Rapat Dengar Pendapat Dengan Komisi VIII DPR RI Tentang Program Pembangunan Bidang Pendidikan Dasar Dan Menengah Tahun 2008 Dengan Capaian Target Wajar Dikdas 9 Tahun 1 Capaian Target Program Wajib Belajar Pendidikan Dasar 9 Tahun. Rabu,23 Januari 2008.

11 Ibid 
menjadi bagian dari satu sistem pendidikan nasional. Mengenai kurikulum pesantren ini dapat dilihat gambar berikut:

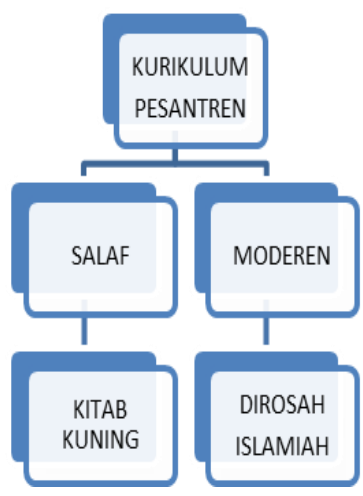

Pesantren modern merupakan satu kebijakan untuk mengembangkan kualitas pesantren. Pesantren sebagai salah satu lembaga pendidikan turut serta mendukung perkembangan pendidikan agama Islam yang berkualitas, yang mampu mengantarkan peserta didik menjadi manusia yang beriman dan bertakwa, berakhlak mulia, berkepribadian, menguasai ilmu pengetahuan dan teknologi, serta mampu mengaktualisasikan diri dalam kehidupan bermasyarakat, berbangsa, dan bernegara.

Di pesantren modern sistem pembelajarannya menerapkan system klasikal terstruktur dengan pengertian sampai belajar di ruang kelas dan di jadwalkan menurut per mata pelajaran dengan pendekatan integratif yaitu tidak adanya dikotomi ilmu agama dan ilmu umum. ${ }^{12}$ Selain belajar Al Quran, Kitab-kitab dan ilmu agama lainya peserta didik pun belajar mata pelajaran lainnya atau pelajaran-pelajaran lainnya, sehingga dapat mengaitkan ilmu-ilmu agama dengan illmu umum atau dengan suasana kehidupan. Ada beberapa kemampuan yang diharapkan dapat dikuasai oleh peserta didik seperti mampu berkomunikasi dalam berbagai bahasa, minimal dua bahasa yaitu bahasa Inggris dan bahasa Arab, sehingga mampu berkomunikasi dan membaca kitab-kitab atau teks berbahasa Arab. Selain itu, peserta didik mampu membaca dan memahami Al Quran, dan mengerti terjemahannya. Bisa menjalankan praktek ibadah dengan baik dan benar. Kemampuan lainnya adalah menguasai dan

12 Muh. Idris Usman. Pesantren Sebagai Lembaga Pendidikan Islam. Jurnal Al Hikmah Vol. XIV Nomor 1/2013.

412 JURNAL LISAN AL-HAL 
memanfaatkan perkembangan ilmu pengetahuan dan teknologi, seperti information and communikation technology (ICT). Dengan kemampuankemampuan yang dimiliki tersebut dapat memberikan bekal kepada peserta didik berupa perilaku yang berkualitas yaitu yang memiliki sains, ilmu pengetahuan dan teknologinya yang baik dan pemahaman dan pengamalan agama yang taat, baik, dan benar.

Kurikulum di pesantren modern di kenal dengan dirosah islamiah dengan pola mualimin (pasal 10 ayat 1 PMA no. 18 2014).13 Maksudnya kurikulum yang menerapkan pembelajaran kitab klasik dengan penguatan bahasa arab dimana pebelajar (santri) dapat secara mandiri menelaah kitab apapun pada masa yang akan datang. Pelaksanaan pembelajaranya di laksanakan di dalam ruang kelas seperti sekolah-sekolah pada umumnya.

Kurikulum Mu'adalah (penyetaraan) diberlakukan pada pondokpondok salaf ataupun modern dengan kreteria dan persyaratan tertentu. Kurikulum pondok pesantren salaf yang memperoleh Mu'adalah atau penyetaraan adalah kurikulum kitab kuning ditambah kurikulum pendidikan umum yang meliputi Kurikulum pendidikan umum sebagaimana dimaksud pada ayat (1) (pasal 10 ayat 3 PMA no. 18 tahun 2014) memuat paling sedikit:

a. pendidikan kewarganegaraan (al-tarbiyah al-wathaniyah);

b. bahasa Indonesia (al-lughah al-indunisiyah);

c. matematika (al-ri.yadhiyat); dan

d. Ilmu pengetahuan alam (al-ulum al-thabi'iyah).

Kurikulum pondok modern yang mendapatkan penyetaraan (Mu'adalah) menggunakan kurikulum dirosah islamiah dengan pola mualimin di tambah kurikulum pendidikan umum seperti yang di maksud diatas. Mengenai pola pemetaan kurikulum ini bisa dilihat gambar berikut;
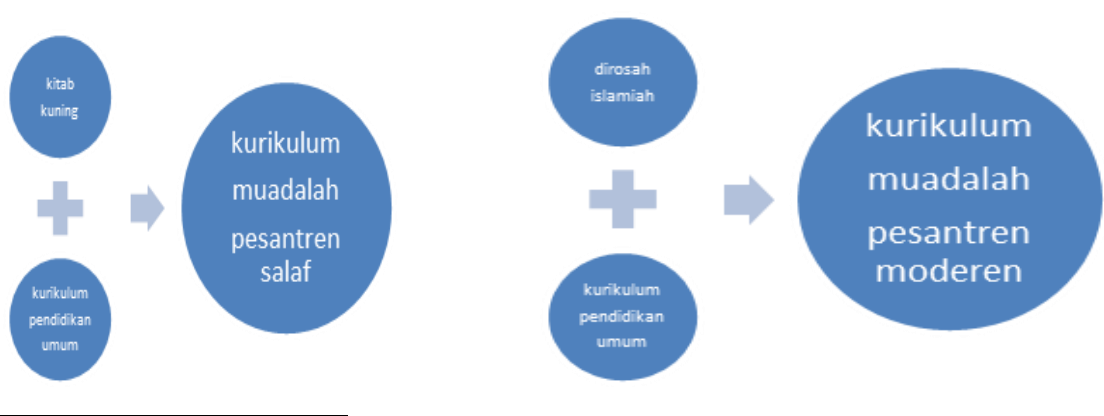

13 PMA No 18 tahun 2014 (PMA No 18 Tahun 2014) pasal 10 ayat 1 Tentang Satuan Pendidikan Mu'adalah Pada Pondok Pesantren Kurikulum satuan pendidikan Mu'adalah terdiri atas kurikulum keagamaan Islam dan kurikulum pendidikan umum. 


\section{Tantangan dan Peluang penerapan kurikulum Mu'adalah pasca diterbitkanya peraturan pemerintah tentang pendidikan pesantren dan diniyah melalui Peraturan Menteri Agama nomor 13 dan 18 tahun 2014}

Dampak globalisasi segala aspek dapat berubah. Perubahan tersebut menurut Zyumardi Azra berlangsung cepat, menyeluruh, mendalam dan serba tak terduga. Cepat, karena perubahan tersebut tak pernah dapat diikuti oleh mereka yang turut terlibat dan yang tak pernah terlibat. Menyeluruh, karena perubahan tersebut menyangkut hampir seluruh segi kehidupan. Mendalam, karena perubahan itu sampai ke detail-detail subyek yang sedang atau lagi berubah. Serba tak terduga, karena perubahan-perubahan itu sering tidak dapat diestimasi dan diramalkan secara jitu. ${ }^{14}$ Friedman sebagaimana yang dikutip HAR Tilaar mengatakan bahwa pada era globalisasi terjadi suatu perubahan yang besar dalam pergaulan umat manusia karena kemajuan teknologi komunikasi, sehingga benar-benar dunia telah menjadi kampung besar (big village). ${ }^{15}$ Gelombang globalisasi telah membawa masalah-masalah baru bagi penyelenggaraan madrasah. Peluang penerapan kurikulum Mu'adalah pasca diterbitkannya Peraturan Menteri Agama nomor 13 dan 18 tahun 2014 yaitu:

Pertama, kurikum Mu'adalah berbeda secara umum dengan kurikulum pada umumnya dimana kurikulum Mu'adalah mengakomodasi kekhasan kurikulum pesantren baik yang pesantren salaf maupun yang modern. Secara jelasnya apa yang di ajarkan pada pesantren yang tersetarakan diakui apa adanya sebagai sebuah kekhasan pesantren tersebut. Contoh: kurikulum yang ada di pondek pesantren Modern Gontor Ponorogo yang telah ada dan melekat pada pesantren tersebut di akui tanpa merubah apapun kurikulum yang sudah berjalan selama berpuluh-puluh tahun selama ini. Hanya saja pemerintah mensyaratkan menambah 4 mata pelajaran kurikulum pendidikan umum yaitu: (1) pendidikan kewarganegaraan (al-tarbiyah al-wathaniyah); (2) bahasa

14 Muhammad Thalhah Hasan, Mutu Pendidikan Islam Sebagai Kunci Jawaban, dalam Epilog Asrori S. Karni, Etos Studi Kaum Santri, Wajah Baru Pendidikan Islam, (Bandung: Mizan Pustaka, 2009), hlm. 413.

15 Ibid,

$414 \mid$ JURNAL LISAN AL-HAL 
Indonesia (al-lughah al-indunisiyah); (3) matematika (al-riyadhiyat); dan (4) ilmu pengetahuan alam (al-ulum al-thabi'iyah).

Kedua, Pesantren Mu'adalah bisa dengan kemandirianya mengembangkan kekhasan pondok pesantren yang tidak dimiliki oleh pendidikan pada umumnya di Indonesia. Dengan memiliki kekhasan kurikulum pesantren yang dikembangkanya, pesantren Mu'adalah dapat membentuk lulusan sesuai dengan keinginanya dan tujuan pesantren karena hal itu dimungkinkan pesantren Mu'adalah memiliki otoritas untuk melakukan hal tersebut tanpa interfensi dari pemerintah atau dari pihak manapun.

Untuk tantangan penerapan kurikulum Mu'adalah pasca diterbitkannya Peraturan Menteri Agama nomor 13 dan 18 tahun 2014 yaitu: Pertama, Kurikulum Mu'adalah tidak mengharuskan santri/murid utuk mengikuti ujian nasional sehingga secara kualitas banyak pihak yang mempertanyakan. Dengan tidak mengikuti ujian nasional dapat diartikan bahwa lulusan pesantren Mu'adalah itu belum terseleksi secara ujian formal dalam arti tidak menjalani tes uji kopetensi ujian nasional. Kedua, peluang masuk di perguruan tinggi terkadang mendapat kendala sebab lulusan pesantren Mu'adalah tidak bisa menunjukan ijasah dan hasil ujian nasional. Lemahnya sosialisasi program Mu'adalah menyebabkan beberapa perguruan tinggi tidak dapat menerima lulusan pesantren Mu'adalah. Apalagi dalam aturan masuk perguruan tinggi tertentu, terdapat klausul bahwa mahasiswa pendaftar harus dapat menunjukan ijasah dan transkrip nilai ujian nasional.

\section{Kesimpulan}

Kurikulum Pendidikan Mu'adalah memberi peluang kepada pesantren untuk mengembangkan kurikulum kekhasan masing-masing dimana pemberian penyeraan tersebuat adalah sebuah penghargaan kepada pesantren yang merupakan tempat lembaga pendidikan tertua di Indonesia. Di sisi lain pemberian penyertaraaan program pendidikan Mu'adalah tersebut sedianya dapat memacu pesantren untuk meningkatkan kualitas sumberdaya manusia agar pelaksanaan kurikulum di pondok pesantren Mu'adalah mendapat pengakuan defakto dan dejure.

Kehadiran era globalisasi yang menimbulkan perubahan di berbagai bidang sangat berpengaruh terhadap eksistensi madrasah di Indonesia. Madrasah salafiyah yang merupakan salah satu variasi bentuk madrasah yang didirikan oleh masyarakat, untuk masyarakat, sampai sekarang masih tetap eksis dan masih bertahan dengan sistem pendidikan tradisionalnya. Walaupun Madrasah Salafiyah sebagai salah satu jenis 
pendidikan keagamaan sudah masuk menjadi sub sistem pendidikan nasional, tetapi masih memiliki kekhasan tersendiri dan belum bisa menyesuaikan secara penuh dengan sistem pendidikan nasional di Indonesia.

\section{Daftar Pustaka}

Albar. Pesantren sebagai pilar bangsa albar66.blogspot.com/2012/01/pesantren-sebagai-pilar bangsa.html.

Departemen Agama RI Paparan Direktur Jenderal Pendidikan Islam Dalam Rapat Dengar Pendapat Dengan Komisi VIII DPR RI Tentang Program Pembangunan Bidang Pendidikan Dasar Dan Menengah Tahun 2008 Dengan Capaian Target Wajar Dikdas 9 Tahun 1 Capaian Target Program Wajib Belajar Pendidikan Dasar 9 Tahun. Rabu,23 Januari 2008.

Dhofier, Zamakhsyari. Tradisi Pesantren. Jakarta: LP3ES. 1983.

Ditjen Pendis Kemenag RI | Analisis Data Pendidikan Islam. pendis.kemenag.go.id/index.php?a=artikel\&id2=analisis2011.

Peraturan menteri Agama repub.lik Indonesia Nomor 13 tahun 2014 Tentang Pendidikan keagamaan islam.

PMA No 18 tahun 2014 (PMA No 18 Tahun 2014) pasal 10 ayat 1 Tentang Satuan Pendidikan Mu'adalah Pada Pondok Pesantren Kurikulum satuan pendidikan Mu'adalah terdiri atas kurikulum keagamaan Islam dan kurikulum pendidikan umum.

PMA No 18 tahun 2014 (PMA No 18 Tahun 2014) Tentang Satuan Pendidikan Mu'adalah Pada Pondok Pesantren

S. Karni, Asrori, Etos Studi Kaum Santri, Wajah Baru Pendidikan Islam, Bandung: Mizan Pustaka, 2009.

Saridjo, Marwan. Bunga Rampai Pendidikan Agama Islam, Jakarta: Dirjen Bimbaga Islam. 1998.

Steenbrink. A. Karel. Pesantren Madrasah Sekolah (Pendidikan Islam Dalam Kurun Waktu Moderen). Jakarta: Dharma Aksara. 1986.

Usman, Muh. Idris. Pesantren Sebagai Lembaga Pendidikan Islam. Jurnal Al Hikmah Vol. XIV Nomor 1/2013

$416 \mid$ JURNAL LISAN AL-HAL 
